\title{
ARCHITECTURAL DESIGN STANDARDS FOR MUSLIMS PRAYER FACILITIES IN AIRPORTS
}

\author{
A. MOKHTAR \\ College of Architecture, Art and Design, American University of Sharjah, United Arab Emirates.
}

\begin{abstract}
Increasingly, airports around the world are becoming hubs for the coexistence of different cultures. Therefore, they need to include facilities that can accommodate, as far as possible, the needs of passengers from various backgrounds. Among these are prayer facilities for people of different faiths. This paper focuses on the design and operational requirements for Muslim prayer facilities. Due to the nature of Muslim prayer patterns, airports that expect to serve Muslim passengers need to have prayer facilities of which the design and operating systems are adequate. Such facilities remove the necessity of Muslims having to pray in public areas in airports and performing ablution in public restrooms. If facilities dedicated to Muslim use are unavailable, the performance of these acts in public places may not only render those who perform them unable to concentrate, but also raise the curiosity of others or make them uncomfortable. The paper firstly describes the need for prayer facilities and the pattern of their use. It then defines the architectural and operational requirements, including location in the airport, the components of the prayer space and supporting elements such as ablution stations. The paper functions as a reference for designers and operators of airports particularly in areas with large Muslim populations, such as the Middle East, Africa, the Indian subcontinent, the Pacific Rim, Central Asia and Europe.

Keywords: ablution space design, airports architecture, Muslim prayer facilities.
\end{abstract}

\section{INTRODUCTION}

'The modern airport, and certainly the airport of the twenty-first century, is a huge, complex and noisy theatre. It is a focus of a wide diversity of human activity from travel to leisure, from shopping to health clubs, from plane-spotting to conferences, and from family reunions to Church outings' [1]. For a sizable proportion of Muslim passengers, prayer is part of this diverse human airport activity. Practicing Muslims pray five times a day (dawn, mid-day, afternoon, sunset and night); each prayer has a window of time for its performance. With this frequency, a Muslim - when travelling - may need to perform a prayer while in transit, waiting to board a plane, or upon arrival at an airport. Religious rulings allow the combination of two prayer periods to ease the burden during travel. In the past, this enabled many to pray before arriving at or after leaving the airport. However, today's long distance flights that transpass time zones, lengthy security and baggage queues, and journey times to and from airports make praying at the airport a more feasible option. It is therefore common in Islamic countries to find a mosque or prayer facilities within an airport, although the quality and sufficiency of such facilities varies. Yet, as the world became better connected, Muslims live and travel in all parts of the world using airports that exist in non-Islamic countries. Some of these airports accommodate the need for practicing Muslims by providing prayer facilities. Similarly, the quality of such facilities varies.

The purpose of this paper is to assist designers and operators of airports in providing a better service to a segment of their clients, many of whom may make a decision regarding a travel route based partially on the availability of quality prayer facilities.

The paper starts with an overview of some aspects of Muslim prayer practices that affect the design and operation of prayer facilities. It then reviews related reference works. The requirements of prayer facilities as applied to airports are discussed and reference is made to other general requirements. Two case studies, one in an Islamic country and one in a non-Islamic country, are analysed to illustrate design requirements as presented in the paper. 


\section{BACKGROUND}

2.1 The nature of Muslim prayer

A brief overview of some essential concepts relating to the nature of Muslim prayer is given below to indicate the requirements of prayer facility design and operation.

- Prayer can be performed only by a person who has ablution status. Maintaining and losing such status is defined by religious rulings. Hence, a number of those who perform prayer need to perform ablutions - an activity that requires the use of water.

- Males and females pray in separate spaces or in separate zones within the same space. It is preferable that they have segregated access to prayer spaces and must have segregated ablution spaces.

- Females do not pray during menstruation; this means that female prayer and ablution spaces may be relatively smaller.

- Certain circumstances, mainly relating to sexual activity, require the taking of a shower before prayer. Although these circumstances rarely occur to airport users, some passengers in transit may have had emissions during sleep, which will require them to have a shower before praying.

\subsection{Review of related work}

Although no published reference work has been found relating to the design of prayer facilities at airports, there are several reference works on the design of mosques. Standard reference books on architecture design, such as Architectural Graphic Standards [2], Neufert Architects' Data [3], and the Metric Handbook [4] provide useful data for some aspects of mosque design. More comprehensive references on mosque design exist, but in the Arabic language [5-7]. These references provide detailed requirements on both the urban planning scale and the architecture design scale.

However, the requirements of mosque design differ in many aspects from those of prayer facilities in public buildings such as airports. More specialised references on the latter type of facilities can be found in Refs. [8, 9]. Design standards for ablution spaces which are service spaces within prayer facilities are available in Ref. [10] and summarised in a video available on YouTube [11]. Prayer facilities in airports are distinctive in some aspects, and therefore a study of their design and operational standards is reported in the following sections.

\section{FACILITY DESIGN AND OPERATIONAL CONSIDERATIONS}

3.1 Number and location of prayer facilities

Number and location of prayer facilities are two critical decisions and are affected by the following factors:

- Size and architectural design of the airport: The greater the distance required for travellers to reach the prayer facility, the better the argument for having more than one facility. Linear and along plan airports tend to justify a non-centralised location, whereas radial plan airports justify a central location.

- Security and operational issues: Passengers should not be required to pass unnecessarily through passport controls or security points to reach the prayer facility. Depending on operational and security procedures, more than one facility may be needed; particularly to serve transit passengers. 


\subsection{Separation of gender}

Males and females pray separately, and it is therefore preferable to have separate, but adjacent, facilities for each gender. If this is not feasible then the same facility can be used by both genders but there should be a clear division in the prayer hall, and separate entrances (see Fig. 4). There should also be separate ablution spaces for each gender.

\subsection{Luggage cart parking and important-baggage rack}

Passengers travel with important documents (e.g. passport and ticket) as well as laptops and other valuables, typically kept in small bags, which cannot be left unattended while performing prayer. Those who pray will typically take these bags into the prayer room with them, but this uses space and may compromise the cleanliness of the room. Prayer actions prevent the carrying of bags on the shoulder, or storage beside the legs. The provision of keyed lockers of sufficient size can address this issue. Alternatively, appropriately sized shelves may be installed in the prayer hall. However, these shelves should be placed where they can be seen by those at prayer, and so will need to be close to the Quibla wall (in the direction of Mecca). If the prayer hall is located where the passengers are expected to have their large pieces of luggage, then a parking area for luggage carts needs to be provided, preferably in a place where the passengers feel secure to leave them. Without this assigned area, luggage carts may be left where they will disrupt the movement of other airport users.

\subsection{Restrooms}

In addition to typical design requirements for restrooms, accommodating some particular requirement for Muslim hygienic practices can be either a must (in airports within the Islamic world) or appreciated efforts (in airports outside the Islamic world). Unless it is unavailable, Muslims use water (not just toilet tissue) for personal cleansing after using the toilet. Therefore, in the Islamic world toilet cubicles typically include a douche installed to the right side of the water closet. That it is on the right side is determined by religious rulings. Mokhtar [9] provides additional details on the requirements for restrooms for Muslims in public buildings.

As mentioned above, in the event of recent sexual activity or emissions, religious rulings require a Muslim to shower before praying. Therefore, providing showers in restrooms is recommended, particularly for transient passengers who may sleep for some hours.

\subsection{Ablution stations}

In line with religious rulings, a Muslim may need to perform ablutions before performing prayer. Ablution stations similar to the one shown in Fig. 1 are typically used for that purpose. More design models for ablution stations are available in Ref. [10]. It is much preferred if ablution stations are installed close to the prayer space. In an airport serving large number of Muslims, it is worth investing in making the relationship between the ablution and prayer space similar to that shown in Fig. 2 where clear separation exists between a clean zone (no shoes) and non-clean zone. The ablution area exists inside the clean zone. If a technical or cost issue prevents having an ablution space close to the prayer hall, then the installation of ablution stations connected to a common restroom is recommended. In this case, the designer should consider that the user needs to take off his/her shoes, perform ablutions which make several parts of the body wet, including the feet, dry these parts (particularly the feet), and put on the shoes again so as to be able to reach the prayer hall. 


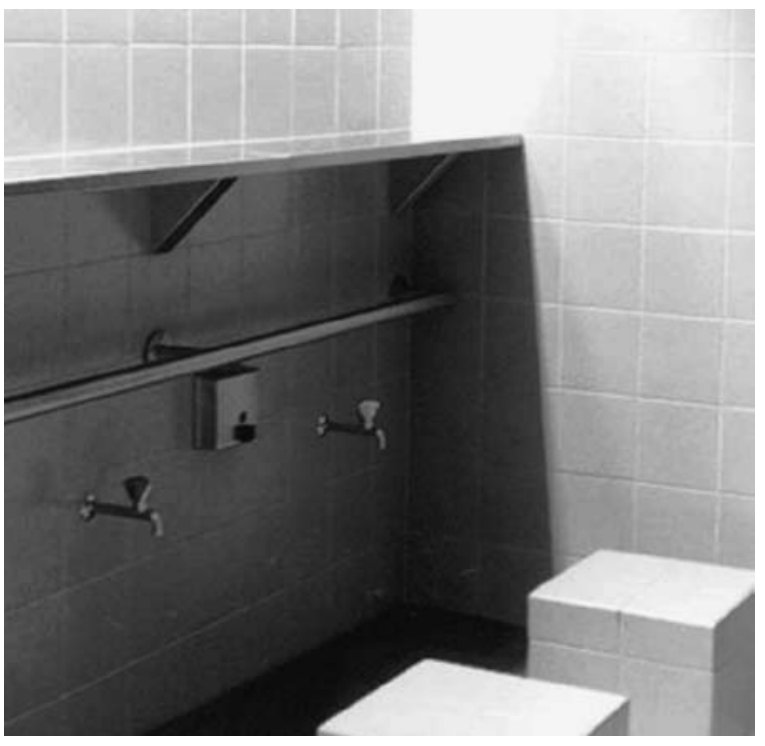

Figure 1: Example of an ablution station (terminal one, Dubai Airport).

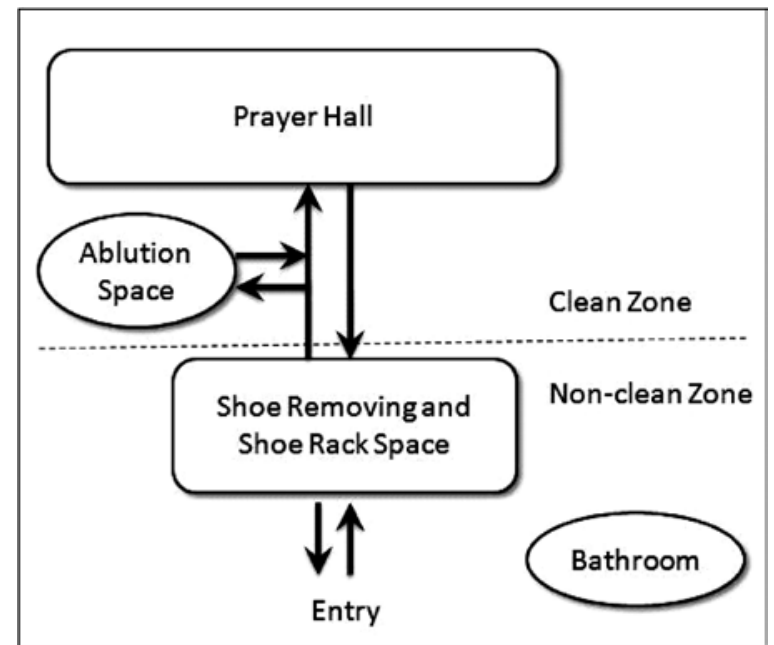

Figure 2: Relationship between spaces in the prayer facility [8].

The designer also should ensure that ablution stations are kept away from urinals and water closet cubicles.

As discussed above, the provision of a shower is recommended. This can be installed in the public restroom or inside the ablution space in case it is close to the prayer hall. The latter solution will be appropriate if it is desired to limit the use of the shower to those who intend to perform prayer. In designing the shower cubicle, it is important to consider the privacy issue through the installation of a locked door rather than a curtain. 


\subsection{Other issues}

3.6.1 Sound system function in the prayer hall

Sound systems that alert travellers to the departure and arrival of planes are standard feature in airport spaces. These sound systems, however, can interfere with prayer sessions, particularly during group prayer. Yet those praying, like other passengers, need to be alerted. The problem can be addressed through having a push button system to control the sound system so that at the start of a group prayer the sound system speakers within the prayer hall may be shut off (or reduced in volume) for the typical duration of the prayer (about $10 \mathrm{~min}$ ).

3.6.2 The provision of female prayer clothes

Religious rulings determine the dress code for males and females during prayer. Typical clothes for men usually adhere to the code. However, females who do not normally cover their head or body in a way that fulfils prayer requirements need to do so. Therefore the provision of light prayer clothes for females is recommended. Naturally, these need to be cleaned and maintained regularly.

3.6.3 The provision of electronic prayer time calculators

As prayer times vary depending on location, Muslims occasionally find it difficult when travelling to know the prayer time for the place they are visiting. The provision of an electronic prayer time calculator in the prayer hall is therefore recommended. This shows the prayer time based on the location's latitude, longitude, and daylight saving time, if used. Some calculators are equipped to make the call for prayer.

\section{CASE STUDIES}

The purpose of the following case studies is to review critically the design of Muslim prayer facilities in two airports, one in the Islamic world (Dubai Airport) and the other outside it (JFK Airport in New York). The purpose is to clarify the concepts presented in the paper.

\subsection{Prayer facilities at terminal one, Dubai Airport}

As may be expected, Dubai Airport serves a large number of Muslim passengers. There are four prayer facilities in Terminal One with other terminals have their own prayer facilities. Each of these four facilities has separate male and female prayer halls and ablution spaces. One facility is located before reaching the limited-access check-in counters in the departure area, and hence serves departing passengers, visitors and employees. Another facility is in the arrival area, but past the customs area, and hence serves arriving passengers, those who wait for them, and employees. The other two facilities are located in the departure hall. Because of the linear design and the length of that hall, two prayer facilities are necessary to reduce the walking distance.

Figure 3 shows a sketch for the design of the facility which is located in the departure hall. One of the advantages of this facility is that it has the ablution space close to the prayer hall, and accessible within the prayer facility. The shoe racks are of adequate size to hold small bags, although they are rarely used for this purpose. Coat hangers are available, together with a shelf, to ease the performance of ablutions (see Fig. 1). A dressing mirror is installed beside the entry door. It is worth noting that the restrooms in the departure hall (which is also the transit area) have showers. 


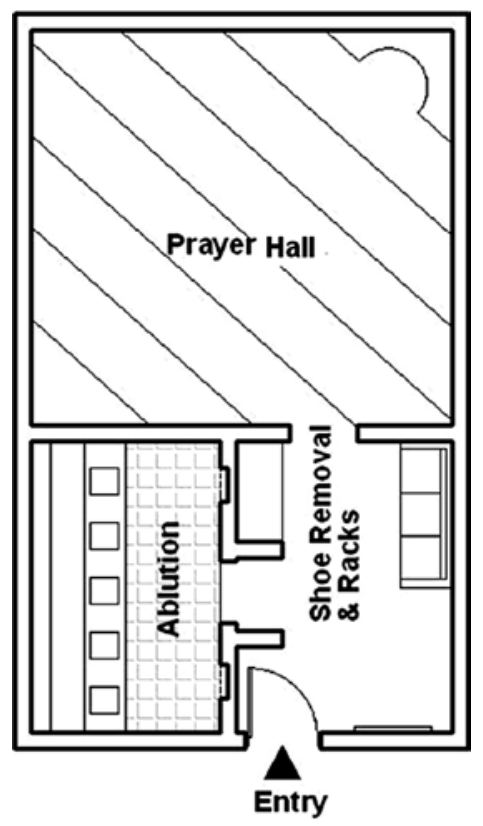

Figure 3: A single-gender Muslim prayer facility at Dubai Airport (not to scale; not exact proportions).

\subsection{Prayer facilities at terminal four, JFK Airport, New York}

The international terminal at JFK Airport in New York is an example of an airport outside the Islamic world that accommodates the prayer needs of practicing Muslims. The Muslim facility - shown in Fig. 4 - is in an airport zone dedicated to the prayer needs of several faiths. The prayer area is located outside the security zone in the departure level, and is not restricted by passport control. As transit passengers have to go through the same procedures as other passengers, the area is also accessible to those passengers. Because the international terminal is connected to other terminals in the airport by the Air Train Shuttle, the area is also accessible to Muslims travelling through other terminals; however, the time and effort required to reach it may be an issue.

Unlike Dubai Airport, males and females share the same prayer hall, although a curtain is installed to separate them. There are shoe racks inside the space, placed appropriately near the entrance. There is sufficient space in front of the entrance to park luggage carts, although those at prayer may not feel comfortable leaving their baggage unattended and out of sight while praying. As at the Dubai Airport, there is no facility for locking up important luggage or keeping it on shelves in sight of the person performing prayer.

The main problem in the JFK facility is the lack of ablution space; users have to go down to the standard washbasin in the restrooms - one floor below - to perform ablution. The ablution process is certainly unfamiliar to non-Muslim users of the same facility. In particular the need to clean the feet, which many Muslims perform by raising them into the washbasin causing confusion for non-Muslim users. It may also make the person performing the ablution uncomfortable for causing such confusion.

\section{SUMMARY AND CONCLUSION}

As airports became hubs for a variety of activities and accommodate the needs for those of different cultures, the provision of adequate prayer facilities for Muslim passengers becomes increasingly important. 


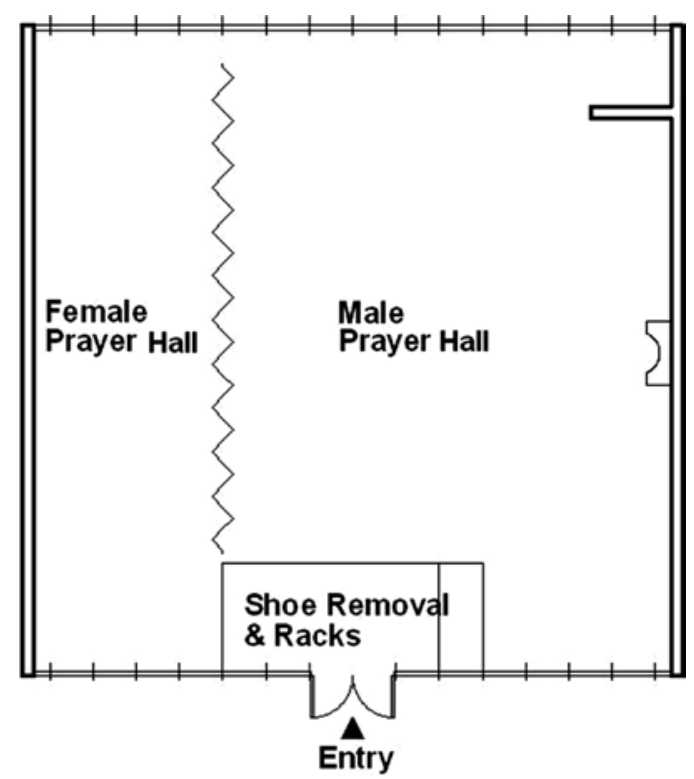

Figure 4: The dual gender Muslim prayer facility at JFK Airport (not to scale; not exact proportions).

This paper provides airport designers and operators with basic information they need to provide this service adequately. The paper focuses on issues relevant to airports in particular, and refers to other sources that address the requirements for prayer facilities in general (which also apply to airports). The paper discusses the location of the prayer facility, the separation of genders, the need for cart parking and luggage racks, special requirements for restrooms, and ablution stations. Two case studies are used to clarify the information.

\section{REFERENCES}

[1] Edwards, B., The Modern Airport Terminal: New Approaches to Airport Architecture, Spon Press: London and New York, p. 260, 2005.

[2] Ramsey, C.G. \& Sleeper, H.R., American Institute of Architects, Architectural Graphic Standards, Wiley \& Sons, Inc.: New Jersey, 2007.

[3] Neufert, E., Neufert, P., Baiche, B. \& Walliman, N., Neufert Architects' Data, Blackwell Science Inc.: Oxford, Malden, Ames, Victoria, and Berlin, 2000.

[4] Littlefield, D., Metric Handbook - Planning and Design Data, Architectural Press: Oxford, 2008.

[5] Directorate-General for Yanbu Project, Planning and design standards for mosque architecture in Madinat Yanbu Al-Sinaiyah. Proceedings of Research on Mosque Architecture, College of Architecture and Planning, King Saud University, Saudi Arabia, vol. 10, pp. 149-180, 1999 (in Arabic).

[6] Ibraheem, H., Planning Standards for Mosques, Ministry of City and Village Affairs: Kingdom of Saudi Arabia, 1979 (in Arabic).

[7] Nofel, M., Design criteria for mosque architecture. Proceedings of Research on Mosque Architecture, College of Architecture and Planning, King Saud University, Saudi Arabia, vol. 5, pp. 75-94, 1999 (in Arabic). 
[8] Mokhtar, A., Design issues for Muslims praying spaces in shopping malls. $2 A-$ Architecture \& Art, No. 9, pp. 86-87, 2008.

[9] Mokhtar, A., Design standards for Muslim prayer facilities within public buildings. ARCC $2009-$ Leadership in Architectural Research, Between Academia and the Profession, San Antonio, TX, 15-18 April 2009.

[10] Mokhtar, A., Design guidelines for ablution spaces in mosques and Islamic prayer facilities, American University of Sharjah: Sharjah, 2006 (in Arabic and English).

[11] Mokhtar, A., Design of ablution spaces - the guide, 2004, documentary video available in two parts on YouTube. Part1: http://www.youtube.com/watch?v=U2H9cNDm0w; Part2: http:// www.youtube.com/watch?v=qKtAMJmixZc. 